\title{
Leptospira spp. infection in sheep herds in southeast Brazil
}

\author{
Priscila Barbante ${ }^{1}$, Fabio H Shimabukuro ${ }^{2}$, Helio Langoni ${ }^{1}$, Virgínia B Richini-Pereira ${ }^{3}$ and Simone B Lucheis ${ }^{4 *}$
}

\begin{abstract}
Background: With the aim of studying Leptospira spp. infection in sheep herds, blood samples and respective kidney and liver fragments were collected from 100 animals from twenty different properties during slaughter at a meat company in the Sorocaba region, São Paulo state, southeast Brazil. The microscopic agglutination test (MAT) was performed with 29 strains of Leptospira spp. To identify the agent in the liver and kidney, 100 samples of each tissue were submitted to culture in Fletcher medium and analyzed by the polymerase chain reaction (PCR) for Leptospira spp.

Results: MAT detected 23 samples serologically positive for one or more Leptospira spp. serovars and significantly more for Autumnalis. Eight (4\%) samples were positive in culture (four kidneys and four livers), corresponding to five animals with positive serology (one animal simultaneously positive for both kidney and liver) and two negatives. PCR detected Leptospira spp. in 14 samples (seven kidneys and seven livers) corresponding to 12 positive animals (two animals simultaneously positive for kidney and liver), of which ten were serologically positive and two negative.
\end{abstract}

Conclusions: PCR was faster, more practical and more sensitive than culture for detecting leptospires. The results reinforce the importance of sheep in the epidemiological context of leptospirosis.

Keywords: Leptospirosis, Ovine, Serology, Culture, PCR

\section{Background}

One of the most representative zoonotic illnesses with a large economic impact on animal production is leptospirosis, an infectious disease that causes a fall in milk production, miscarriages, and low fertility. It is also a serious public health problem related to socioeconomic characteristics, floods, and occupational aspects in humans [1]. Azevedo et al. [2] were alerted to the transmission of the disease in slaughterhouse workers who had handled the organs and carcasses of infected animals.

Leptospira has been observed in the urine, semen and vaginal secretions of production animals, characterizing these species as susceptible to the disease from the reproductive sphere [3].

\footnotetext{
* Correspondence: silucheis@apta.sp.gov.br

${ }^{4}$ Paulista Agency of Agribusiness Technology (APTA/SAA), Av. Rodrigues Alves, 40-40, Bauru, SP CEP 17030-000, Brazil

Full list of author information is available at the end of the article
}

Ovine Leptospira spp. seems to be common in most countries, particularly in extensive flock management systems where sheep farming occurs together with cattle, allowing infection by direct contact with urine or by contaminated water in collective drinking supplies $[4,5]$.

Infection of sheep was first detected in Brazil by Santa Rosa and Castro [6] in animals from São Paulo state, $34 \%$ of which were found to be reactive to various Leptospira spp. serovars.

Later serological studies performed by Viegas et al. [7], found $22.8 \%$ of sheep reactive, mainly to Autumnalis, Castellonis, Grippotyphosa, and Tarassovi serovars. In another work performed in Bahia, Caldas et al. [8] observed $34.7 \%$ of a sample of 800 examined sheep to be reactive, most frequently to the serovars Autumnalis, Castellonis and Butembo.

Langoni et al. [9] studied antileptospira agglutinins in 356 ovine serum samples from different regions of São Paulo state, finding the following prevalences: Icterohaemorrhagiae (51.25\%); Castellonis (20.63\%), Hardjo (19.36\%); Bratislava (16.25\%); Andamana and Wolffi 
(11.88\%); Copenhageni (8.75\%); Grippotyphosa (4.34\%); Pomona (2.5\%), and Tarassovi (0.63\%).

A work performed by Martins and Lilenbaum [10] in Rio de Janeiro, Brazil, reported the highest prevalence of seroreactivity in sheep $(47.4 \%)$, in relation to the other species of ruminants studied, including cows and goats.

In 11 municipalities in the Presidente Dutra microregion, Maranhão state, Brazil, Carvalho et al. [11] analyzed 379 sheep blood serum samples using a microscopic agglutination test (MAT); of the 37 herds studied, 30 (81\%) had at least one seropositive animal while the individual seroprevalence was $32 \%$.

A study performed in the state of Rio Grande do Sul verified by MAT that from 1360 tested serum samples, 466 (34.26\%) animals were reactive with antileptospira agglutinin counts varying from 100 to 3200 . The main serovars encountered were: Hardjo (28.4\%), Sentot (16.8\%); and Hardjoprajitno (14.5\%), showing that Leptospira spp. is spread on most farms that raise sheep in the southeast and southwest mesoregions of Rio Grande do Sul [12].

A study by Escócio et al. [13] analyzed the sanitary profile of sheep flocks farmed exclusively or together with cattle in the Sorocaba region of São Paulo state. High levels of leptospirosis were found and all flocks were reactive to at least one serovar of Leptospira spp. Autumnalis was most prevalent serovar in four sheep flocks, followed by the Pyrogenes; in seven flocks where both cattle and sheep were in the same environment, the most prevalent were the serovars Icterohaemorrhagiae, Hardjo and Javanica.

Sheep flock infection by Leptospira leads to serious economic losses, represented by physiological problems and reproductive alterations. In this context, the aim was to verify the occurrence of antileptospira antibodies in sheep from different municipal areas in the Sorocaba region, São Paulo state, that were slaughtered in meat plants, to study the presence of serologically positive and negative sheep as renal Leptospira spp. carriers (chronic phase) and detect the agent in the liver (acute phase) by culturing in Fletcher medium using the Pasteur pipette technique and by PCR.

\section{Methods}

\section{Animals and samples}

We sampled 100 sheep from 20 properties from different municipal areas of Sorocaba region, São Paulo state, southeast Brazil. Samples were taken at moment of slaughter, selecting five animals from each property.

During the bleeding phase, approximately $10 \mathrm{~mL}$ of blood was collected from each animal in a $15 \mathrm{~mL}$ sterile glass tube. After coagulant removal, samples were centrifuged at $3000 \mathrm{rpm}$ for 15 minutes and the serum obtained was treated in a $1.5 \mathrm{~mL}$ microtube and frozen at $-20^{\circ} \mathrm{C}$ for later serological testing.
Fragments from the liver and the left or right kidney were aseptically collected during the disembowelment phase. These were placed individually in plastic bags, sealed and identified, refrigerated in an isothermal box, and transferred to the laboratory.

\section{Microscopic Agglutination Test (MAT)}

MAT was performed as per Ministry of Health norms [14]. Each serum sample was initially diluted 1:100 in $\mathrm{pH} 7.2$ phosphate buffered saline (PBS) as a positive cutoff point. Live cultures of 29 strains of Leptospira spp., used as antigens, were grown in liquid culture medium of Ellinghausen-McCullough-Johnson-Harris (EMJH), free of contamination or self-agglutination: L. interrogans serovars Australis, Autumnalis, Bataviae, Bratislava, Canicola, Copenhageni, Djasiman, Wolffi, Icterohaemorrhagiae, Pomona, Sentot, Hardjo, Hardjoprajitno, Hardjobovis, HardjoCTG and Hardjominiswajezak; $L$. santarosai serovar Shermani; L. borgpetersenii serovars Castellonis, Hebdomadis, Javanica, Pyrogenes, Tarassovi and Whitcombi; L. kirschneri serovars Butembo, Cynopteri and Grippotyphosa; L. noguchi serovar Panama and L. biflexa serovars Andamana and Patoc.

Considered positive were those serovars that presented $50 \%$ or more agglutination than the control. Samples found positive in the first titer were successively rediluted at 1:2 and tested for the previously reacting serovars. The last titer was that which still presented $50 \%$ or more agglutination [15].

\section{Leptospira spp. isolation}

The liver and kidney fragments used for culture were processed as cited by Passos et al. [16]. The obtained material was cultivated in three tubes with Fletcher culture medium, two with an additional $100 \mu \mathrm{g} 5$ fluorouracil $/ \mathrm{mL}$ and $2.5 \mu \mathrm{g}$ neomycin, and one without antibiotics, all incubated at $29^{\circ} \mathrm{C}$ for 16 weeks. Readings were made fortnightly after seeding; samples were considered positive when mobile spirochetes were seen under a dark field microscope at $400 \times$.

\section{Polymerase Chain Reaction (PCR)}

Fragments of liver and kidney weighing between 5 and $50 \mathrm{mg}$ were pre-titrated with the aid of sterile pincers and bistoury and placed in sterile $1.5 \mathrm{~mL}$ DNAse and RNAse-free microtubes. After $1 \mathrm{~mL}$ of pH7.2 sterile PBS was added, the samples were centrifuged at 19,000 $\mathrm{g}$ for 15 minutes (kidney) and 19,000 g for 30 minutes (liver) at $4^{\circ} \mathrm{C}$ according to Heinemann et al. [17] with some modifications for tissue wash; supernatant was discarded and $50 \mu \mathrm{L}$ of $\mathrm{pH} 7.2$ sterile PBS was added to the cellular sediment, which was then macerated with a biovortexer (Biospec Inc., USA) and centrifuged at $2000 \mathrm{~g}$ for ten seconds. 
The DNA extraction from liver and kidney was performed using an illustra Tissue \& Cells Genomic Prep Mini Spin Kit (GE Healthcare, USA), as per the manufacturer's recommendations and concentration was measured in a spectrophotometer (NanoVue, GE Healthcare, USA).

Molecular detection was carried out through PCR by using the primer pair: LEP1 (5'GGCGGCGCGTCTTA AACATG3') and LEP2 (5'TTCCCCCCATTGAGCAA GATT3'), that amplified 331 bp for Leptospira spp. [18].

PCR reactions was performed in $0.2 \mathrm{~mL}$ microtubes with total volumes of $25 \mu \mathrm{L}$, containing PCR buffer solution $\left(50 \mathrm{mM} \mathrm{KCl}, 10 \mathrm{mM}\right.$ of Tris- $\mathrm{HCl} \mathrm{pH} \mathrm{8.0),} \mathrm{MgCl}_{2}$ (1.5 mM), dNTP solution (0.2 mM), Taq Platinum DNA (1.0 U) (Invitrogen, Brazil), $10 \mathrm{pM}$ of each primer, ultrapure water (Life Technologies, USA) and DNA (10 ng).

Amplification was performed in a Mastercycler ${ }^{\oplus}$ EP Gradient Thermal Cycler (Eppendorf, Germany). Thermal cycling conditions were $94^{\circ} \mathrm{C}$ for three minutes, 30 cycles of $94^{\circ} \mathrm{C}$ for one minute, annealing at $63^{\circ} \mathrm{C}$ for one minute, and extension at $72^{\circ} \mathrm{C}$ for two minutes, with an additional ten minutes at $72^{\circ} \mathrm{C}$ at the end to complete extension of the amplified segments. Visualization of amplified products was accomplished by electrophoresis. For this $1.5 \%$ agarose gel was prepared with $1 \mu \mathrm{L} / \mathrm{mL}$ SYBR $^{\oplus}$ Safe DNA gel stain (Life Technologies, USA). PCR product $(10 \mu \mathrm{L})$ and $4 \mu \mathrm{L}$ of $100 \mathrm{bp}$ molecular ladder (Life Technologies, USA) were used. To all samples, $2 \mu \mathrm{L}$ of a BlueJuice ${ }^{\mathrm{TM}}$ Gel Loading Buffer (Life Technologies, USA) was added. The gel was submitted to the electrophoresis run in an HE99 horizontal cube (GE Healthcare, USA) containing $1 \mathrm{X}$ TBE (0.1 M Tris, $0.09 \mathrm{M}$ boracic acid, and 0.001 M EDTA) at $100 \mathrm{~V}$ for approximately one hour using an electrophoresis power supply (EPS 301, GE Healthcare, USA). The gel was visualized in a UV transilluminator and the image captured by a GelDoc-It ${ }^{\oplus}$ TS Imaging System (UVP, USA) and documented using VisionWorks ${ }^{\ominus}$ LS Image Acquisition and Analysis Software (UVP, USA). Controls were used for extraction and PCR technique. Contaminated liver and kidney suspensions were prepared with $L$. interrogans serovar Pyrogenes at $2.0 \times 10^{4}$ leptospires/ $\mathrm{mL}$ as the positive control, and ultrapure water (Life Technologies, USA) as the negative control.

Analytical sensitivity was tested using different known negative tissue samples (liver and kidney) by contaminating the samples with $L$. interrogans serovar Pyrogenes at concentrations of approximately $2.0 \times 10^{0} ; 2.0 \times 10^{1}$; $2.0 \times 10^{2} ; 2.0 \times 10^{3}$, and $2.0 \times 10^{4}$ microorganisms per milliliter of suspension from each organ sample [19].

\section{Results}

From the 20 properties studied, 13 (65\%) presented at least one seropositive animal. From the total 100 serum samples analyzed by MAT, 23 (23\%) were reactive to one or more Leptospira spp. serovar.

Of the 29 Leptospira spp. serovars tested, only nine were reactive. Most animals were reactive to the Autumnalis serovar $(n=19)$ with titers varying from 100 to 1600 . Other reactive serovars were Patoc $(n=3)$, Butembo $(n=$ $2)$, Castellonis $(n=1)$, Djasiman $(n=1)$, Grippothyphosa $(\mathrm{n}=1)$, Icterohaemorrhagiae $(\mathrm{n}=1)$, Wolffi $(\mathrm{n}=1)$ and Hardjo Prajitno $(n=1)$, whose titers varied from 100 to 200. The highest titer obtained was 1600 for Autumnalis serovar in a single animal (Table 1).

In the culture results, from the 20 properties studied, we found five (25\%) positive from at least one animal. Of the liver and kidney samples from 100 animals submitted to culture in Fletcher medium, four liver samples (three with and one without antibiotic) and four kidney samples (three with and one without antibiotic) were positive for Leptospira spp., corresponding to seven animals. Only one animal presented simultaneous positivity in both organs. Microorganisms were observed in the culture after one month of incubation at $29^{\circ} \mathrm{C}$, confirmed by visualization of spirochetes in a dark field microscope. No opalescence ring formation was seen (Dinger zone).

PCR results from the 20 properties studied revealed that eight $(40 \%)$ were positive for Leptospira spp. in at least one animal. In liver and kidney samples from 100 animals submitted to PCR, seven liver and seven kidney samples were positive for Leptospira spp., corresponding to 12 animals. Two sheep were positive for both kidney and liver samples. The analytical sensitivity was $2.0 \times 10^{2}$ leptospires/mL.

Out of the 20 properties analyzed, 13 (65\%) were reactive by at least one of the diagnostic tests used. Twenty-three animals were reactive by MAT, seven were positive in the Fletcher medium culture, and twelve were positive by PCR (Table 2).

\section{Discussion}

Due to the paucity of data on the prevalence of leptospirosis in sheep flocks from different municipalities of the state of São Paulo, this study aimed to verify the occurrence of Leptospira spp. in different properties of the Sorocaba region, São Paulo state, using slaughterhouses as a strategic sample collection point. Thus, it was possible to establish the occurrence of leptospirosis in the flocks studied and highlight the most frequent serovars of Leptospira spp. from these regions.

According to serological results, 65\% of the properties had positive animals, indicating that leptospirosis is present in the majority of sheep flocks in the Sorocaba region, thus demonstrating the importance of this disease in these animals. 
Table 1 Distribution of Leptospira spp. serovars and antibody titers from sheep herds in Sorocaba region, São Paulo state, southeast Brazil

\begin{tabular}{|c|c|c|c|c|c|c|c|c|c|c|c|c|c|}
\hline \multirow[t]{3}{*}{ Property } & \multirow{3}{*}{$\begin{array}{c}\text { Animals } \\
\text { analyzed/positive }\end{array}$} & \multicolumn{12}{|c|}{ Serovars } \\
\hline & & \multicolumn{3}{|c|}{ Autumnalis } & \multirow{2}{*}{$\frac{\text { Butembo }}{100}$} & \multirow{2}{*}{$\frac{\text { Castellonis }}{100}$} & \multirow{2}{*}{$\frac{\text { Djasiman }}{100}$} & \multirow{2}{*}{$\frac{\text { Grippothyphosa }}{100}$} & \multirow{2}{*}{$\frac{\text { Icterohaemorrhagiae }}{200}$} & \multirow{2}{*}{$\frac{\text { Wollfi }}{200}$} & \multicolumn{2}{|c|}{ Patoc } & \multirow{2}{*}{$\frac{\text { Hardjoprajitno }}{100}$} \\
\hline & & 100 & 200 & 1600 & & & & & & & 100 & 200 & \\
\hline$A$ & $5 / 1$ & 1 & - & - & - & - & - & - & - & - & - & - & - \\
\hline B & $5 / 0$ & - & - & - & - & - & - & - & - & - & - & - & - \\
\hline C & $5 / 1$ & 1 & - & - & - & - & - & - & - & - & - & - & - \\
\hline D & $5 / 2$ & 1 & 1 & - & - & - & - & - & - & - & - & - & - \\
\hline $\mathrm{E}$ & $5 / 2$ & 1 & 1 & - & - & - & - & - & - & - & - & - & - \\
\hline $\mathrm{F}$ & $5 / 1$ & 1 & - & - & - & - & - & - & - & - & - & - & - \\
\hline G & $5 / 2$ & 1 & 1 & - & - & - & - & - & - & - & - & - & - \\
\hline $\mathrm{H}$ & $5 / 2$ & 1 & 1 & - & - & - & - & - & - & - & - & - & - \\
\hline 1 & $5 / 0$ & - & - & - & - & - & - & - & - & - & - & - & - \\
\hline J & $5 / 1$ & - & 1 & - & - & - & - & - & - & - & - & - & - \\
\hline L & $5 / 3^{\mathrm{a}}$ & 1 & 2 & - & 1 & - & - & - & - & - & - & - & - \\
\hline$M$ & $5 / 3^{b}$ & 1 & 1 & - & - & - & - & - & - & 1 & - & 1 & - \\
\hline $\mathrm{N}$ & $5 / 0$ & - & - & - & - & - & - & - & - & - & - & - & - \\
\hline 0 & $5 / 0$ & - & - & - & - & - & - & - & - & - & - & - & - \\
\hline$P$ & $5 / 0$ & - & - & - & - & - & - & - & - & - & - & - & - \\
\hline $\mathbf{Q}$ & $5 / 1$ & - & - & - & - & - & 1 & - & - & - & - & - & - \\
\hline$R$ & $5 / 1$ & - & 1 & - & - & - & - & - & - & - & - & - & - \\
\hline$S$ & $5 / 0$ & - & - & - & - & - & - & - & - & - & - & - & - \\
\hline $\mathrm{T}$ & $5 / 0$ & - & - & - & - & - & - & - & - & - & - & - & - \\
\hline U & $5 / 3^{C}$ & 1 & - & 1 & 1 & 1 & - & 1 & 1 & - & 1 & - & 1 \\
\hline Total & $100 / 23$ & 10 & 9 & 1 & 2 & 1 & 1 & 1 & 1 & 1 & 1 & 1 & 1 \\
\hline
\end{tabular}

ane animal reactive to two serovars, Autumnalis (200) and Butembo (100).

bOne animal reactive to two serovars, Autumnalis (200) and Patoc (200).

'One animal reactive to two serovars, Autumnalis (100) and Castellonis (100) and another to five serovars, Autumnalis (1600), Butembo (100), Grippothyphosa (100), Icterohaemorrhagiae (200), and Patoc (100).

(-) non-reactive animals. 
Table 2 Results for microscopic agglutination test (MAT), culture and PCR of liver and kidney from sheep herds in Sorocaba region, São Paulo state, southeast Brazil

\begin{tabular}{|c|c|c|c|c|c|}
\hline \multicolumn{2}{|c|}{ Culture } & \multirow[t]{2}{*}{ MAT } & \multicolumn{2}{|c|}{ PCR } & \multirow{2}{*}{$\begin{array}{c}\text { Number } \\
\text { of animals }\end{array}$} \\
\hline Liver & Kidney & & Liver & Kidney & \\
\hline- & - & - & - & - & 75 \\
\hline- & - & + & - & - & 13 \\
\hline- & - & + & - & + & 3 \\
\hline- & + & + & - & + & 1 \\
\hline- & + & - & - & + & 1 \\
\hline- & + & + & + & + & 1 \\
\hline+ & + & + & + & + & 1 \\
\hline+ & - & - & + & - & 1 \\
\hline- & - & + & + & - & 2 \\
\hline+ & - & + & + & - & 2 \\
\hline
\end{tabular}

The positive serology found in this study can be linked to previous contact with the etiological agent without disease development until the presence of ill carrier animals [20].

The most important probable infecting serovar was Autumnalis. This result corroborates the investigation by Viegas et al. [7] and Caldas et al. [8] in Bahia. This contrasts with Herrmann et al. [12], who reported Hardjo as the most prevalent serovar in sheep in Rio Grande do Sul state and Lilenbaum et al. [21], who observed that the most important serovars in Rio de Janeiro were Hardjo and Shermani.

Autumnalis is commonly isolated in wild animals, especially rodents, which could indicate them as possible leptospirosis transmitters in the sheep flocks studied [22]. This hypothesis is supported by the form of extensive farming observed in the present study.

Other probable infecting serovars were Djasiman, Hardjoprajitno, Wolffi, and Patoc, each reactive in only one animal. Wolffi and Hardjoprajitno are linked to the infection in bovines, Djasiman is found in wild animals, whereas Patoc is observed as a saprophytic serovar [23].

Some studies have demonstrated certain evidence that sheep are maintenance hosts for Hardjo, serving as a reservoir for bovines [24]. However, only one animal in this study demonstrated probable infection from this serovar.

Most reactive animals presented low antileptospirosis antibody titers, probably due to prior contact with the antigen. Only one animal presented a high titer of 1600 for Autumnalis with co-agglutination for other serovars, thus presenting serological reaction characteristic of acute infection [20].

Of the Leptospira spp. cultures from 100 renal and 100 hepatic samples cultured in Fletcher medium with and without antibiotic, eight were positive (four kidney and four liver) corresponding to five animals with positive serology (one was simultaneously positive in both kidney and liver) and two negatives. The isolation rate was $4 \%(8 / 200)$, better than values obtained by Azevedo et al. [2].

The low Leptospira spp. isolation rate could be dependent on various factors including type of medium used, serovar involved, sample processing time, type of material collected from the aseptic form, contamination, and selection of antibiotics used [25].

Failure to isolate the agent in the other 18 serologically positive animals could be explained by dealing with animals that had been in contact with a Leptospira without evolution of infection or disease or even by the factors cited by Thiermann et al. [25].

On the other hand, two serologically negative animals presented positive isolation, one for the kidney and the other for the liver. This exposes two probable scenarios: for the liver, the animal was in the initial infection phase without presenting MAT-detectable antibody titers; and in the kidney, the animal may have been infected by a different serovar than those tested in MAT without there being a cross-reaction.

Although this is a laborious, slow high-cost technique requiring months for results with little success in isolating the agent, identifying the serovar is highly important in epidemiological studies, as the isolated agent can be studied later to improve pathogen characterization and study its pathogenicity and other relevant analyses.

The presence of viable leptospires in the liver and kidneys of apparently healthy sheep at slaughter adds weight to the possibility of the disease being transmitted to the slaughterhouse and to meat packers who handle these materials. Furthermore, animal renal carriers could transmit the agent to rural workers from direct contact with urine or the contaminated environment.

The PCR of 100 renal and 100 kidney samples detected leptospires in 7\% (14/200) samples (seven kidney and seven liver) corresponding to 12 positive animals (two animals were simultaneously positive for kidney and liver). Of the 23 serologically positive animals, leptospires were detected in ten while two did not present detectable antibodies by MAT.

Although PCR detected a higher positive sample rate than the culture technique, 13 serologically positive animals were negative. This can also be explained by what happened in culture, namely the absence of leptospire isolation in 18 seropositive sheep, probably because the animals had contact with the agent; but there was no progression of the disease.

The PCR technique was more practical and faster in detecting Leptospira spp. than culture in Fletcher medium and has the possibility of improving the sensitivity of 
diagnostic techniques in the early phase of infection and/ or disease [19].

MAT is the worldwide reference test for leptospirosis diagnosis with high sensitivity and specificity. However, some difficulties with interpretation exist: there is a limitation in establishing whether serologically positive animals really are infected. Also, verification of a cross-reaction between different serovars can impede the establishment of the infecting serovar.

The presence of antileptospire antibodies often does not reflect the current situation of infection or the disease in animals, but rather only establishes host immunological response, which could be from prior contact without development of infection or the disease. This can be verified in the present study by the large number of serologically leptospire positive and negative animals from culture or PCR. This is reinforced by the weak concordance between serology and the agent's presence in studied tissue.

In comparing the techniques and their concordance proportion, results from culture and PCR techniques in both tissues (liver and kidney) presented a good concordance (Kappa of 0.97). But when the results are analyzed only by looking at positive samples, of the seven positive liver and kidney samples by PCR, three were negative in both tissues in culture, corresponding to $42.8 \%$ negativity; in other words culture detected 42.8 times less than PCR. In addition, the sensitivity results from the two techniques for detecting the agent, taking serologically positive animals as the basis, showed PCR to be more sensitive than culture. This has also been found in other comparison studies [18].

The results from the three diagnostic techniques shows the probable stages of infection in the sheep, in agreement with Levett [20]. Seventy-five animals were negative in all tests performed, indicating absence of infection; thirteen animals were positive only in serology, probably indicating prior contact with the etiological agent without disease development, or an animal after the convalescence phase that is no longer a renal carrier, but still presents detectable antibodies (immunological memory). Four animals were serologically positive with kidney culture and/or PCR positive, which probably indicates chronic infection and renal colonization stage (renal carrier) with detectable antibodies. Four serologically positive animals that had liver culture and/or PCR positive were probably found in the acute infection phase, in leptospiremia and with detectable antibodies, but still without renal colonization. Two positive animals by both liver and kidney culture and/or PCR were possibly in the end acute stage, still with leptospiremia, detectable antibodies, and renal colonization. One animal was serologically negative with kidney culture and/or PCR positive, which suggests an infection by a serovar other than those used in the battery of antigens in MAT, it did not present cross-reaction to the tested serovars, and was found in the convalescence and renal carrier phase. Another serologically negative animal with positive liver culture and/or PCR probably had a recent infection, with leptospiremia, but still without detectable antibodies or renal colonization.

According to the probable infection stage found in animals with positive hepatic culture and/or PCR, seven sheep (30.4\%) from the 23 serologically positive animals presented acute phase infection, which could indicate that infection is persistent on these properties.

\section{Conclusions}

The occurrence of Leptospira spp. among sheep herds from Sorocaba region, state of São Paulo, Brazil, was $23 \%$ whereas the most important probable infecting serovar was Autumnalis, as determined by MAT. PCR was faster, more practical and sensitive than culture for detecting Leptospira spp. Our results reinforce the importance of sheep in the epidemiological context of leptospirosis in Brazil.

\section{Ethics committee approval}

The present study was approved by the Ethics Committee on Animal Experimentation of the School of Veterinary Medicine and Animal Husbandry, São Paulo State University (UNESP), Botucatu, SP, Brazil, under protocol number $95 / 2008$.

\section{Competing interests}

The authors declare that there are no competing interests.

\section{Authors' contributions}

PB participated in the design of the study, carried out the blood collection, performed the diagnostic tests, the analysis of the results and took part in the article writing. FHS and $\mathrm{HL}$ participated in the analysis of the results. VBRP participated in the analysis of the results and article writing. SBL participated in the design of the study, the analysis of the results and article writing. All authors read and approved the final manuscript.

\section{Acknowledgments}

The authors would like to thank the State of São Paulo Research Foundation (FAPESP) for the scholarship (2008/52537-0) and financial support (2008/ 53714-2) and the Regional Laboratory of Sorocaba - Adolfo Lutz Institute.

\section{Author details}

'Department of Veterinary Hygiene and Public Health, School of Veterinary Medicine and Animal Husbandry, São Paulo State University (UNESP - Univ Estadual Paulista), Botucatu, São Paulo State, Brazil. ${ }^{2}$ Adolfo Lutz Institute, Sorocaba, São Paulo State, Brazil. ${ }^{3}$ Adolfo Lutz Institute - CLR II, Bauru, São Paulo State, Brazil. ${ }^{4}$ Paulista Agency of Agribusiness Technology (APTA/SAA), Av. Rodrigues Alves, 40-40, Bauru, SP CEP 17030-000, Brazil.

Received: 31 October 2013 Accepted: 17 April 2014

Published: 6 May 2014

\section{References}

1. Leptospiroses. In Enfermidades infecciosas dos mamíferos domésticos. Edited by Corrêa WM, Corrêa CNM. Rio de Janeiro: Medsi; 1992:219-231. 
2. Azevedo SS, Alves CJ, Andrade JSL, Santos FA, Freitas TD, Batista CSA: Isolation of Leptospira spp. from kidneys of sheep at slaughter. Arq Inst Biol São Paulo 2004, 71(3):383-385.

3. Lilenbaum W, Varges R, Brandão FZ, Cortez A, de Souza SO, Brandão PE, Richtzenhain L, Vasconcellos SA: Detection of Leptospira spp. in semen and vaginal fluids of goats and sheep by polymerase chain reaction. Theriogenology 2008, 69(7):837-842.

4. Ellis WA, Bryson DG, Neill SD, McParland PJ, Malone FE: Possible involvement of leptospires in abortion, stillbirths and neonatal deaths in sheep. Vet Rec 1983, 112(13):291-293.

5. Ellis GR, Partington DL, Hindmarsh M, Barton MD: Seroprevalence to Leptospira interrogans serovar hardjo in merino stud rams in South Australia. Aust Vet J 1994, 71(7):203-206.

6. Santa Rosa CA, Castro AFP: Presença de aglutininas anti-leptospira em soros de ovinos e caprinos no Estado de São Paulo. Arq Inst Biol São Paulo 1963, 30:93-98.

7. Viegas EA, Viegas SARA, Caldas EM: Aglutininas anti-leptospira em hemo-soro de caprinos e ovinos no Estado da Bahia. Arq Esc Med Vet Univ Fed Bahia 1980, 5(1):20-34

8. Caldas EM, Sampaio MB, Viegas EA, Viegas SARA, Dias EMM: Aglutininas antileptospira em ovinos e caprinos na região Nordeste do Estado da Bahia. Arq Esc Med Vet Univ Fed Bahia 1983, 8(1):88-98.

9. Langoni H, Marinho M, Baldini S, Silva AV, Cabral KG, Silva ED: Pesquisa de aglutininas anti-leptospiras em soros ovinos do Estado de São Paulo, Brasil, utilizando provas de macroaglutinação em placa e soroaglutinação microscópica. Rev Bras Med Vet 1995, 17(6):264-268.

10. Martins G, Lilenbaum W: The panorama of animal leptospirosis in Rio de Janeiro, Brazil, regarding the seroepidemiology of the infection in tropical regions. BMC Vet Res 2013, 9:237. doi:10.1186/1746-6148-9-237. [http://www.biomedcentral.com/1746-6148/9/237]

11. Carvalho SM, Mineiro AL, Castro V, Genovez ME, Azevedo SS, Costa FA: Leptospirosis seroprevalence and risk factors for sheep in Maranhão state, Brazil. Trop Anim Health Prod 2014, 46(2):491-494.

12. Herrmann GP, Lage AP, Moreira EC, Haddad JPA, Resende JR, Rodrigues RO, Leite RL: Soroprevalência de aglutininas anti-Leptospira spp. em ovinos nas Mesorregiões Sudeste e Sudoeste do Estado do Rio Grande do Sul, Brasil. Ciênc Rural 2004, 34(2):443-448.

13. Escócio CF, Genovez ME, Castro V, Paulin LMS, Piatti RM, Okuda LH, Gabriel FHL, Chiebao DP, Felicio PS, Almeida MCS: Perfil sanitário de rebanhos ovinos criados exclusivamente ou consorciados com bovinos na região de Sorocaba - São Paulo. In $35^{\circ}$ Congresso Brasileiro De Medicina Veterinária: 19-22 Out 2008, Gramado, RS. Gramado: Conbravet; 2008 [http://www. sovergs.com.br/conbravet2008/anais/cd/resumos/R0693-2.pdf]

14. Brasil. Ministério da Saúde. Secretaria de Vigilância em Saúde: Guia Leptospirose: Diagnóstico e Manejo Clínico. Ministério da Saúde, Secretaria de Vigilância em Saúde, 2009. Em. ftp://ftp.cve.saude.sp.gov.br/doc_tec/ZOO/ LEPTO09_GUIA_MANEJO.pdf.

15. World Health Organization: Guidelines for the control of leptospires. Geneva: WHO Offset Publication; 1982.

16. Passos EC, Vasconcellos SA, Ito FH, Yasuda PH, Nürmberger Junior R: Isolamento de leptospiras a partir do tecido renal de hamsters experimentalmente infectados com Leptospira interrogans sorotipo pomona. Emprego das técnicas da pipeta Pasteur e a das diluições seriadas em meios de cultura de Fletcher tratado com 5-fluor-uracil ou o sulfato de neomicina. Rev Fac Med Vet Zootec Univ São Paulo 1988, 25(2):221-235

17. Heinemann MB, Garcia JF, Nunes CM, Gregori F, Higa ZM, Vasconcellos SA, Richtzenhain LJ: Detection and differentiation of Leptospira spp. serovars in bovine semen by polymerase chain reation and restriction fragment length polymorphism. Vet Microbio/ 2000, 73(4):261-267.

18. Mérien F, Amouriaux P, Perolat P, Baranton G, Saint-Girons I: Polymerase chain reaction for detection of Leptospira spp. in clinical samples. J Clin Microbiol 1992, 30(9):2219-2224.

19. Shimabukuro $F H$, Domingues $P F$, Langoni $H$, Silva AV, Pinheiro JP, Padovani CR: Pesquisa de suínos portadores renais de leptospiras pelo isolamento microbiano e reação em cadeia pela polimerase em amostras de rins de animais sorologicamente positivos e negativos para leptospirose. Braz J Vet Res Anim Sci 2003, 40(4):243-253.

20. Levett PN: Leptospirosis. Clin Microbiol Rev 2001, 14(2):296-326.

21. Lilenbaum W, Varges R, Ristow P, Cortez A, Souza SO, Richtzenhain LJ, Vasconcellos SA: Identification of Leptospira spp. carriers among seroreactive goats and sheep by polymerase chain reaction. Res Vet Sci 2009, 87(1):16-19.

22. da Silva RC, Zetun CB, Gimenes Bosco SM, Bagagli E, Rosa PS, Langoni H: Toxoplasma gondii and Leptospira spp. infection in free-ranging armadillos. Vet Parasitol 2008, 157(3-4):291-293.

23. Salaberry SRS: Epidemiologia das principais doenças infecciosas de ovinos do município de Uberlândia, MG. Thesis 2010. Faculdade de Medicina Veterinária, Universidade Federal de Uberlândia.

24. Gerritsen MJ, Koopmans MJ, Peterse D, Olyhoek T: Sheep as maintenance host for Leptospira interrogans serovar hardjo subtype hardjobovis. Am J Vet Res 1994, 55(9):1232-1237.

25. Thiermann AB: Leptospirosis: current developments and trends. J Am Vet Med Assoc 1984, 184(6):722-725.

doi:10.1186/1678-9199-20-20

Cite this article as: Barbante et al.: Leptospira spp. infection in sheep

herds in southeast Brazil. Journal of Venomous Animals and Toxins

including Tropical Diseases 2014 20:20.

\section{Submit your next manuscript to BioMed Central and take full advantage of:}

- Convenient online submission

- Thorough peer review

- No space constraints or color figure charges

- Immediate publication on acceptance

- Inclusion in PubMed, CAS, Scopus and Google Scholar

- Research which is freely available for redistribution

Submit your manuscript at www.biomedcentral.com/submit
C) Biomed Central 